\title{
EFFECT OF MORINGAOLEIFERA LEAVES EXTRACT AGAINST ACETAMINOPHEN INDUCED HEPATOTOXICITY IN ALBINO RATS.
}

\author{
Shahenda, M. Elaby, Nivin, S. Nail and Sanaa, A. Mahfouz \\ ${ }^{1}$ Regional Center for Food and Feed, Agriculture Research Center, Giza, Egypt.
}

\begin{abstract}
This study was carried out to evaluate the the effect of moringaoleiferaleavesExtract against liver injury induced by APAP in rats. The experimental animals were divided into six groups of male albino rats. Aqueous extract of Moringaoleifera (AMO) and hydroalcoholic extract of Moringaoleifera (HAMO) were prepared and pre-administered orally to rats at dose $500 \mathrm{mg} / \mathrm{kg}$ body weight; p.ofor a period of 28 days prior to a singleoraldose of APAP 3 $\mathrm{g} / \mathrm{kg}$ body weight; p.o.The results showed that APAP induced a significant rise in the activities of aspartate amino transferase(AST), alanine amino transferase (ALT), alkaline phosphatase (ALP) and the level of malondialdehyde (MDA)besides reduction in the activities of glutathione reductase (GR), superoxide dismutase (SOD) and catalase (CAT).The activities of AST, ALT, ALP and the level of MDAwere significantly decreasedwhilethe activities of GR, SOD and CATwere significantlyincreased in rats preadministered with HAMO and AMO priorto APAP treatmentcompared to the group treated with APAP alone. Rats pre-administered with HAMO priorto APAP treatmenthave provided more significant protectioninthe activities of liver enzymes and antioxidants enzymes than rats pre-administered with AMO priorto APAP treatment.Pre-administered of HAMO and AMO significantly prevented the hepatocellularchanges associated with APAPtreatment.The results from the present study suggestedthat the two extracts of moringaoleiferaleaves (HAMO and AMO) possess a remarkablehepatoprotective and antioxidantactivity against APAP induced hepatotoxicity.
\end{abstract}

\section{INTRODUCTION}

The liver is the most important organ in the body. It plays a bivotal role in regulating various physiological processes (Ahsan et al., 2009). The role played by this organ in the removal of substances from the portal circulation makes it susceptible to first and persistent attack by offending foreign compounds, culminating in liver dysfunction (Bodakhe and Ram, 2007). Liver diseases have become one of the major causes of morbidity and mortality all over the world. Among them, drug induced liver injury is one of the most common causative factor that poses a major clinical and regulatory challenge (Russmann et al., 2009).

Acetaminophen (APAP) is a widely used medication for the treatment of pain and fever in children and pregnant women. Initiation of (APAP) toxicities is believed to be promoted by oxidative stress of liver during the event of overdosage. Acetaminophen is an effective and widely used antipyretic-analgesic drug with excellent safety record when taken at therapeutic doses (Larson, 2007). Despite extensive efforts to conduct studies on the processes of APAP induced toxicity, the exact mechanisms are still incompletely understood. Most evidence suggested the depletion of glutathione and the formation of reactive metabolites is somehow triggers the cascade events of hepatotoxicity. Overdose of APAP results in the generation of free radicals following the depletion of glutathione (Jaeschke and Bajt, 2006). 
Moringaoleifera L (Moringaceae) known commonly as Ben oil tree or drumstick tree in English language, 'Okweoyibo' in Igbo, 'Gawara' or 'Habiwal' in Hausa and 'Adagbamaloye' or 'Ewe Igbale' in Yoruba grows rapidly in most regions and climatic conditions of Nigeria. M. oleifera is an important food commodity which has had enormous attention as the 'natural nutrition of the tropics' (Anwar et al., 2007). A number of medicinal properties have been ascribed to various parts of this tree. Most parts of this plant: root, bark, gum, leaves, fruit (pods) flowers, seed and seed oil have been used in folk medicine in Africa and South Asia (Fahey, 2005). It has been used for the treatment of inflammation, infectious diseases, cardiovascular, gastrointestinal, hematological and hepatorenal disorders (Siddhuraju and Becker, 2003). Most of plants uses for medicinal purposes have been correlated to their possession of antioxidant activity (Sofidiya et al., 2006). Plants and their products are potential sources of phytochemicals that have been found to counteract free radicals due to their antioxidant activity (Khalafalla $\boldsymbol{e t}$ al., 2010). The antioxidant activity of Moringaoleifera extracts is due to the presence of various bioactive compounds such as chlorogenic acid, rutin, quercetinglucoside, and kaempferolrhamnoglucoside(Atawodi et al., 2010). The leaves are highly essential nutritious when compared to other parts, being a source of protein, $\beta$-carotene, $\mathrm{B}, \mathrm{C}$ and $\mathrm{E}$, riboflavin, nicotinic acid, folic acid, pyridoxine, amino acids, minerals and various phenolic compounds (Khalafalla et al., 2010). Also Moyoet al. (2012) suggested that $M$. oleifera could be a potential source of polyphenoliccompounds with strong antioxidant potential. M. oleifera leaves protected the tissues against oxidative stress in rats. This profound protective effect of $M$. oleiferamay explain its extensive use in daily life and possible health benefits (Vermaet al., 2009). The present study aimed to evaluate the hepatoprotective of ethanol and aqueous extract of the leaves of Moringaoleifera L against Acetaminophen (APAP) induced hepatotoxicity in rats.

\section{MATERIALS AND METHODS}

\section{Materials:}

\section{Chemicals:}

Acetaminophen was purchased from Sigma Chemical Co. (St Louis, MO, USA)and solvents were purchased from Merck (Darmstadt, Germany).Kits used for the estimation of analyzed parameters were purchased from Biosystem, Spain and Biodiagnostic, France.

\section{Plant material:}

Moringaoleifera (MO) leaves powder was obtained from National Research Center, Dokki, Cairo, Egypt.

\section{Corn starch, corn oil, cellulose and sucrose:}

Corn starchand corn oil were purchased from the local market while sucrose and cellulosewere purchased from Sigma Chemical Co. (St Louis, MO, USA).

\section{Mineral salts and vitamins:}

Mineral salts and vitaminsused for the preparation of the mineral salt and vitamin mixtures were obtained from Sigma Chemical Co. (St Louis, MO, USA) and prepared according to AIN-1993 (Reeves et al., 1993). 


\section{Animals:}

Adult male albino rats weighing $(120 \pm 5 \mathrm{~g})$ were obtained from Faculty of Veterinary Medicine, CairoUniversity.

\section{Methods:}

\section{Plant materials and extraction:}

The dried leaves powder wasstored in polyethylene bags in refrigerator at $4{ }^{\circ} \mathrm{C}$ until further use. $10 \mathrm{~g}$ of leaves powder was extracted using $100 \mathrm{ml}$ boiling distilled water or $80 \%$ hydroalcoholic solvent ( $80 \%$ ethanol: $20 \%$ distilled water) with constant shaking at room temperature for overnight. The two extracts were filtered and the residue were then resuspended in boiling distilled water or $80 \%$ hydroalcoholic solvent for another 24 hours and refiltered. The two filtrates were then concentrated using a rotary evaporator (RV 10 digital, Germany)under reduced pressure at $40{ }^{\circ} \mathrm{C}$ and then lyophilized using a freeze dryer(Labconco, Model Lyph. Lock 6). The two dark green mass were obtained and stored at $-20{ }^{\circ} \mathrm{C}$ until further use. The two crude extracts, wereresuspended in distilled water before administration to the animals.

\section{APAPinduction of liver injury:}

Liver injury was induced by an oral administration of $3 \mathrm{~g} / \mathrm{kg}$ APAP in $40 \%$ sucrose buffer, $1 \mathrm{ml} / \mathrm{kg}$ body weight, on day 28 (Fakurazi et al., 2008).

\section{Experimental animals and study design:}

The animals were housed in separated cage and maintained under control laboratory conditions at $25^{\circ} \mathrm{C} \pm 2{ }^{\circ} \mathrm{C}$ on a $12 \mathrm{~h}$ light: $12 \mathrm{~h}$ dark cycle for a week with free access to standard food and water ad libitum. The animals were handled accordance to the rules and regulations by the animal's house of RegionalCenter for Food and Feed, AgricultureResearchCenter, Giza, Egypt. Standard foodconsists of corn starch $62.5 \%$ casein $14 \%$, sucrose $10 \%$, cellulose $5 \%$ corn oil $4 \%$, salt mixture $3.5 \%$ and vitamin mixture $1 \%$.Treatment consisted of pretreatment phase of MO in distilled water followed by the second phase in which the animals were given $3 \mathrm{~g} / \mathrm{kg}$ APAP in $40 \%$ sucrose buffer on day 28. During the experimental period(four weeks), the body weight of animals was recorded.The animals were divided into six groups each consisting of 5 ratsas follows:

Group A served as normal control group.

Group B served as hepatotoxin control group which animals received a single dose of APAP ( $3 \mathrm{~g} / \mathrm{kg}$ body weight; p.o) on day 28 .

Group C animals were pre-administered with AMO extract $(500 \mathrm{mg} / \mathrm{kg}$ body weight; p.o)for 28 days

GroupD animals werepre-administered with HAMO extract ( $500 \mathrm{mg} / \mathrm{kg}$ body weight; p.o)for 28 days

GroupE animals werepre-administered with AMO (500 mg/kg body weight; p.o)for 28 days before being intoxicated with APAP.

Group F animals were pre-administered with HAMO extract ( $500 \mathrm{mg} / \mathrm{kg}$ body weight; p.o) for 28 days before being intoxicated with APAP.

Twenty-four hours after APAP administration, all ratswere anesthetized with diethyl ether and blood samples were collected from theretro-orbital veinusing a glass capillary tube. Animals were then sacrificed by cervical decapitationand liver from each group was excised, washed in ice-cold saline to remove blood and duly weighed. 


\section{Biochemical assay:}

The serum and plasma were separated and collected into sterilized tubes and stored at $-20^{\circ} \mathrm{C}$ for biochemical parameters. Serum was separated by centrifuging (Hettich, Universal 16 , German)at $3000 \mathrm{rpm}$ for $20 \mathrm{~min}$ at $4^{\circ} \mathrm{C}$. Activities of serum enzymes AST and ALT were assayed according to the methods of Gella et al., (1985) while ALPwas determinedaccording to themethod of Rosalki et al., (1993).Plasma was prepared by collect blood using an anticoagulant heparin andseparated by centrifuging at $4000 \mathrm{rpm}$ for $10 \mathrm{~min}$ at $4{ }^{\circ} \mathrm{C}$ for antioxidant studies. The activities of GR, SODand CATwere measured accordingto the method reported by Goldberg and Spooner (1983), Nishikimi et al. (1972) and Aebi (1984), respectively. Thelevelof lipid peroxidation was determined as malondialdehyde (MDA) according to themethod reported by Onkawa, (1979).

\section{Histopathologicalstudies:}

Liver from each group wasfixed in $10 \%$ buffered formalin and embedded in the paraffin. Microtome sections of 3-4 $\mu \mathrm{m}$ thickness were prepared according to the standard procedure and stained with haematoxylin and eosin. Sections were then examined for pathological findings of such as centrilobular necrosis, fatty and lymphocytes infiltration by the light microscope (Banchroft et al., 1996).

\section{Statistical analysis:}

Statistical analysis of the obtained data was done using the least significant difference test (LSD) at the 5\% level of probability as outlined by Snedecor and Cochran (1980). Using the Duncan test institute program used a computer in the statistical analysis.

\section{RESULTS AND DISCUSSION}

\section{Body andliver weights:}

The body weight and relative liver weight of each group are found in Table (1).There are no significant differences in the initialbody weights, final body weights, body weight gains and relative liver weights among thesix groups of animals. These results arein the line with the findings of Brown et al. (2012) who found that the body weights were similar between all treatment groups at $4 \mathrm{~h}$ after APAP administration. Also these results are inagreement with Adedapoet al. (2009) who demonstrated that the aqueous extract ofthe leaves of Moringaoleifera did not cause any significant change in the weight of liver. Also similar trend was observedby Oinamet al.(2012) who also did not showed any significant difference in weight gain, final weight and mean weight of liver between rats in different treatments after 8 weeks of supplementation with Moringaoleifera. 
Table (1) Effect of MOLextracts on body weight and relative liver weight of APAP-induced hepatotoxicity in rats.

\begin{tabular}{|l|c|c|c|c|}
\hline \multirow{2}{*}{ Treatment groups } & \multicolumn{3}{|c|}{ Body weight (g) } & \multirow{2}{*}{$\begin{array}{c}\text { Relative liver } \\
\text { weight }\end{array}$} \\
\cline { 2 - 4 } & Initial & Final & Gain & $5.67 \pm 0.13^{\mathrm{a}}$ \\
\hline Group A (Normal control) & $124.8 \pm 0.97^{\mathrm{a}}$ & $156.0 \pm 0.71^{\mathrm{a}}$ & $31.2 \pm 1.36^{\mathrm{a}}$ & $5.77 \pm 0.28^{\mathrm{a}}$ \\
\hline Group B (APAP) & $124.0 \pm 0.71^{\mathrm{a}}$ & $155.4 \pm 1.21^{\mathrm{a}}$ & $31.4 \pm 1.25^{\mathrm{a}}$ & $5.540 .32^{\mathrm{a}}$ \\
\hline GroupC (AMO) & $124.0 \pm 0.95^{\mathrm{a}}$ & $155.6 \pm 1.78^{\mathrm{a}}$ & $31.6 \pm 1.44^{\mathrm{a}}$ & $5.54 .32^{\mathrm{a}}$ \\
\hline Group D (HAMO) & $124.0 \pm 0.55^{\mathrm{a}}$ & $156.6 \pm 0.93^{\mathrm{a}}$ & $32.6 \pm 1.33^{\mathrm{a}}$ & $5.95 \pm 0.31 .0 .39^{\mathrm{a}}$ \\
\hline Group E(AMO +APAP) & $124.2 \pm 0.66^{\mathrm{a}}$ & $155.2 \pm 1.66^{\mathrm{a}}$ & $31.0 \pm 1.14^{\mathrm{a}}$ & $5.81 \pm 0.36^{\mathrm{a}}$ \\
\hline Group F (HAMO +APAP) & $124.0 \pm 0.71^{\mathrm{a}}$ & $155.2 \pm 0.58^{\mathrm{a}}$ & $31.2 \pm 0.97^{\mathrm{a}}$ & $5.85 \pm 0.01$ \\
\hline LSD P $<0.05$ & 2.25 & 3.58 & 3.66 & 0.91 \\
\hline
\end{tabular}

Values are mean \pm SE of 5 rats. Within the same column, various superscript letters indicate significant differences (Duncan, $\mathrm{P}<0.05$ ).

\section{Determination of liver enzymesactivity:}

Liver function tests help in the diagnosis of any abnormal/normal condition of liver. Leakage of cellular enzymes into serum indicates the sign of hepatic tissue damage. The serum activities of liver enzymes ALT, AST and ALP are shown in Table (2). Rats treated with $3 \mathrm{~g} / \mathrm{kg}$ APAP has significant elevation of ALT, AST and ALP activities (58, 54 and 347 U/l, respectively) when compared to those groups pre-administered with HAMO and AMOextracts prior to APAP treatment. Our results are consistent with Fakurazi et al. (2008) whosuggested that rats treated with a single high dose of APAP ( $3 \mathrm{~g} / \mathrm{kg}$ body weight;p.o)have significantly elevatedthe serum transaminases and ALP activities.Meanwhile Hamza(2010) found that treatment with Moringaoleifera has completely blocked the $\mathrm{CCl}_{4}$-induced elevation of serum ALT and AST activities. Another study by Nadroet al. (2005)has alsoshowed thatMO leaves extract hasprevented the release of these enzymes from hepatocytes intothe bloodstream when induced with high level of ethanol administrationin rats.

The reduction in the activities of ALT, AST and ALP enzymes in group that was preadministered with HAMO extract prior to APAP treatmentwere more significantly pronounced $(45,40$ and $326 \mathrm{U} / \mathrm{l}$, respectively) compared to the group that was preadministered with AMOextract prior to APAP treatment (50, 45 and335 U/1, respectively).The observed results could be due to different degreeof polarity of the solvents used for the extraction of polyphenoliccompounds. Similar observation was demonstratedby Vermaet al. (2009) who reported the leaves of M.oleifera, have higher amount of phenols(gallic, chlorogenic, ellagic and ferulic acid) and flavonoids (kaempferol, quercetin and rutin), which areprotected the tissuesagainst $\mathrm{CCl}_{4}$ induced oxidative stress in rats.

Meanwhile, no significant differences were observed in the liver enzymes activities between the rats administeredwithHAMO (33,36 and312 U/1, respectively) and AMOextracts (33, 36 and311 U/l, respectively) when compared to normal control group (33, 36 and313 U/1, respectively). 
Table (2) Effect of MOLextracts on liver enzymes activitiesof APAP-induced hepatotoxicity in rats.

\begin{tabular}{|r|c|c|c|}
\hline \multirow{2}{*}{ Treatment groups } & \multicolumn{3}{|c|}{ Biochemical parameters } \\
\cline { 2 - 4 } & ALT (U/l) & AST (U/l) & ALP (U/l) \\
\hline Group A (Normal control) & $33 \pm 1.14^{\mathrm{d}}$ & $36 \pm 0.51^{\mathrm{d}}$ & $313 \pm 1.44^{\mathrm{d}}$ \\
\hline Group B (APAP) & $58 \pm 1.16^{\mathrm{a}}$ & $54 \pm 1.36^{\mathrm{a}}$ & $347 \pm 1.78^{\mathrm{a}}$ \\
\hline Group C (AMO) & $33 \pm 0.81^{\mathrm{d}}$ & $36 \pm 1.14^{\mathrm{d}}$ & $311 \pm 0.86^{\mathrm{d}}$ \\
\hline Group D (HAMO) & $33 \pm 0.68^{\mathrm{d}}$ & $36 \pm 0.84^{\mathrm{d}}$ & $312 \pm 0.84^{\mathrm{d}}$ \\
\hline Group E (AMO +APAP) & $50 \pm 0.86^{\mathrm{b}}$ & $45 \pm 0.92^{\mathrm{b}}$ & $335 \pm 1.52^{\mathrm{b}}$ \\
\hline Group F (HAMO +APAP) & $45 \pm 1.30^{\mathrm{c}}$ & $40 \pm 0.51^{\mathrm{c}}$ & $326 \pm 1.76^{\mathrm{c}}$ \\
\hline LSD P $<0.05$ & 2.97 & 2.71 & 4.14 \\
\hline
\end{tabular}

Values are mean $\pm \mathrm{SE}$ of 5 rats. Within the same column, various superscript letters indicate significant differences (Duncan, $\mathrm{P}<0.05$ ).

\section{Determination ofantioxidantsenzymes activities and levels of MDA:}

Antioxidant enzymes including GR, SOD and CAT are important enzymes for preventing liver damage by oxidative stress. Antioxidant enzyme activity (GR, SOD and CAT) and the levels of MDAin each group are presented in Table (3). Twenty-four hours after APAP administration, rats treated with a single high dose of APAP has caused remarkabl reducedin the activities of antioxidant enzymesGR, SOD and CAT (20.0, 334 and $29.6 \mathrm{U} / \mathrm{ml}$, respectively) besides elevatingthe levels of MDA $(29.6 \mathrm{nmol} / \mathrm{ml})$ when compared to those groups pretreated with HAMO and AMO extracts prior to APAP treatment.Das and Kanodia (2012) reported that the treatment with ethanolic extract ofMoringaoleiferaleaves inhibits the decrease of CAT and SOD level and increase of MDA in rat treated with acetic acid.

Pre-treatment of rats with HAMO extract for 28 days prior to APAP administration caused more significant depletion in the MDA level $(18.0 \mathrm{nmol} / \mathrm{ml})$, while improving the activities of antioxidant enzymes GR, SOD and CAT (25.0, 344 and $37.6 \mathrm{U} / \mathrm{ml}$, respectively) than group that was pretreated with AMO extract prior to APAP administration, at 21.8 $\mathrm{nmol} / \mathrm{ml}$ for MDA level and 23.0, 339 and $34.6 \mathrm{U} / \mathrm{mlfor}$ GR, SOD and CAT activities, respectively. This may be due to high phenolic and flavonoid content ofmethanolicleaves extract of $M$. oleiferaas found by Siddhuraju and Becker, (2003). Our findings are in accordance with the results of Vermaet al.(2009) who found that co-treatment of rats with polyphenolic fraction of $M$. oleifera leaves at a dose of $50 \mathrm{mg} / \mathrm{kg}$ and $100 \mathrm{mg} / \mathrm{kg} / \mathrm{day}$, for 14 days significantly inhibited the toxicity produced by $\mathrm{CCl}_{4}$ administration as seen from the decreased lipid peroxides (LPO) and increased in SOD and CAT activities and glutathione (GSH) levels near to normal levels.

In addition, no significant differences were observed in the antioxidant enzymes activities GR, SOD and CAT between the rats pretreated with HAMO (29.0, 360 and 43.0U/ml, respectively) and $A M O$ extracts $(28.0,360$ and $43.2 \mathrm{U} / \mathrm{ml}$, respectively) when compared to normal control group $(29.0,357$ and $43.2 \mathrm{U} / \mathrm{ml}$, respectively). Also similar trend was observed in the MDA levels of rats pretreated with HAMO and AMO (14.2 and 14.0 $\mathrm{nmol} / \mathrm{ml}$, respectively). 
Table (3): Effect of MOLextracts on antioxidants enzymes activities and levels of MDAin APAP-induced hepatotoxicity in rats.

\begin{tabular}{|c|c|c|c|c|}
\hline \multirow{2}{*}{ Treatment groups } & \multicolumn{4}{|c|}{ Biochemical parameters } \\
\hline & GR (U/ml) & SOD (U/ml) & CAT $(\mathrm{U} / \mathrm{ml})$ & MDA (nmol/ml) \\
\hline $\begin{array}{l}\text { Group A (Normal } \\
\text { control) }\end{array}$ & $29.0 \pm 0.40^{\mathrm{a}}$ & $357 \pm 4.54^{\mathrm{a}}$ & $43.2 \pm 0.37^{\mathrm{a}}$ & $14.0 \pm 0.45^{\mathrm{d}}$ \\
\hline Group B (APAP) & $20.0 \pm 0.51^{\mathrm{d}}$ & $334 \pm 1.36^{\mathrm{c}}$ & $29.6 \pm 0.87^{\mathrm{d}}$ & $29.6 \pm 0.81^{\mathrm{a}}$ \\
\hline Group C (AMO) & $28.0 \pm 0.98^{\mathrm{a}}$ & $360 \pm 1.89^{\mathrm{a}}$ & $43.2 \pm 0.58^{\mathrm{a}}$ & $14.0 \pm 0.71^{\mathrm{d}}$ \\
\hline Group D(HAMO) & $29.0 \pm 0.55^{\mathrm{a}}$ & $360 \pm 1.36^{\mathrm{a}}$ & $43.0 \pm 0.55^{\mathrm{a}}$ & $14.2 \pm 0.37^{\mathrm{d}}$ \\
\hline Group E (AMO +APAP) & $23.0 \pm 0.68^{\mathrm{c}}$ & $339 \pm 0.51^{b c}$ & $34.6 \pm 0.51^{\mathrm{c}}$ & $21.8 \pm 0.86^{b}$ \\
\hline $\begin{array}{c}\text { Group F (HAMO } \\
\text { +APAP) }\end{array}$ & $25.0 \pm 0.66^{b}$ & $344 \pm 1.21^{b}$ & $37.6 \pm 0.51^{b}$ & $18.0 \pm 0.71^{\mathrm{c}}$ \\
\hline LSD P $<0.05$ & 1.91 & 6.48 & 1.71 & 1.97 \\
\hline
\end{tabular}

Values are mean \pm SE of 5 rats. Within the same column, various superscript letters indicate significant differences (Duncan, $\mathrm{P}<0.05$ ).

\section{Effect of MOLextracts on liver histopathology of APAP-induced hepatotoxicity in rats}

Fig. (1),showed the histopathological examination of liver sections of untreated controlrats (group A) revealsnormal histological structure of hepatic lobule (a). Also liver sections of rats from group $\mathrm{C}$ and $\mathrm{D}$ whichpre-administered with AMO and HAMO extracts respectivelyshowed normal histological structure of hepatic lobules (c and d).Conversely, examined liver sections of rats from group B whichtreated with $3 \mathrm{~g} / \mathrm{kg}$ APAP sacrificed after 24 hoursshowed coagulation necrosis and apoptosis of hepatocytes associated with inflammatory cells infiltration (b). Whereas, liver sections of rats from group E whichpreadministered with AMOextractprior to treatment 3g/kg APAP sacrificed after 24 hours demonstratedhydropic degeneration of hepatocytes and kupffer cells activation (e). Meanwhile, liver sections of rats from group $F$ which pre-administered with HAMO extractprior to treatment $3 \mathrm{~g} / \mathrm{kg}$ APAP sacrificed after 24 hours showed slight activation of kupffer cells (f). A similar observation has been reported by Ahmad et al. (2012) who showed that oral administration of APAP inducedrenal damage by inducing apoptotic hepatocytes, centrilobularnecrosis and inflammation in renal tubular cells. On the otherhand these results are in agreement with Uma et al. (2010) who found that pre-treatment of MO significantly prevented the hepatocellularchanges associated with paracetamol (PCM) intoxication. Meanwhile, the hydroalcoholic extract of MO alone did not induce any hepatocellular damage and similar to those animalsin the control groups. 

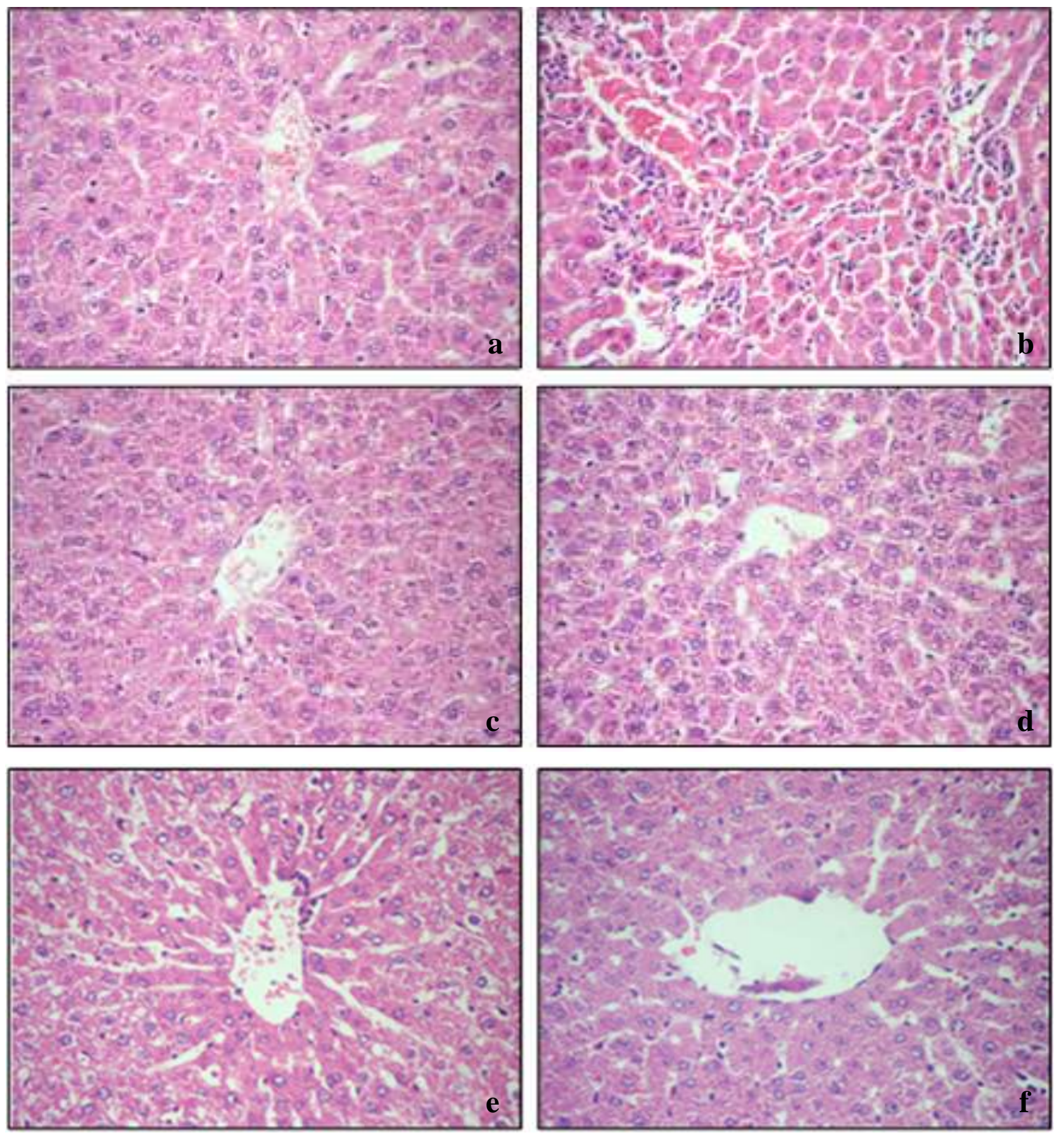

Fig.(1). Photomicrographs of liver histopathologyafterpre-administration with AMO and HAMO extracts in APAP-induced hepatotoxicity in rats (hematoxylin and eosin,400×).a: Normal control; b: APAP hepatotoxin control (3 g/kg b. w); c: AMO (500 mg/kg b.w); : HAMO (500 mg/kg b.w); e: AMO (500 mg/kg b.w) + APAP (3 g/kg b. w); f:.HAMO (500 mg/kg b.w) + APAP (3 g/kg b. w). 


\section{CONCLUSIONS:}

The present investigation showed that a single high dose of APAP administration (3 $\mathrm{g} / \mathrm{kg}$ body weight) has significantly elevatedthe activities of AST, ALT, ALP enzymes and the level of MDAbesides reducingthe activities of antioxidant enzymes GR, SODand CAT. .According to these results, we suggested that the aqueous and ethanol extractsof M. oleifera leaveswere found to have significantly prevented the changes seen inthe liver enzymes activities,MDAlevel, antioxidant enzymes activities and protected the liver tissuesagainst APAP induced hepatotoxicityin rats. The antioxidant potential may be attributed to thepresence of polyphenolic compounds. The protectiveeffect of $M$. oleifera may explain its extensive use in life andpossible health benefits.

\section{REFERENCES}

Adedapo, A.A.; Mogbojuri, O.M. and Emikpe, B.O. (2009): Safety evaluations of the aqueous extract of the leaves of Moringaoleifera in rats. Journal of Medicinal Plants Research, 3(8):586-591.

Aebi, H. (1984): Catalase in vitro. In: Packer L (ed), Methods in Enzymology 105, pp 121126, Academic Press, Orlando.

Ahmad, S. T.; Arjumand, W.; Nafees, S.; Seth, A.; Ali, N.; Rashid, S. and Sultana, S. (2012): Hesperidin alleviates acetaminophen induced toxicity in wistar rats by abrogation of oxidative stress, apoptosis and inflammation. Toxicology Letters, 208: 149-161.

Ahsan, M.R.; Islam, K.M. and Bulbul, I.J. (2009): Hepatoprotective activity of methanol extract of some medicinal plants against carbon tetrachloride-induced hepatotoxicity in rats. Eur J Sci Res; 37(2): 302-310.

Anwar, F.;Latif,S.;Ashrat, M. and Gilani,A.H. (2007): Moringaoleifera: A food plant with multiple medicinal uses. Phytother. Res., 21: 17-25.

Atawodi, S.E.; Atawodi, J.C.; Idakwo, G.A.; Pfundstein, B.; Haubner, R.; Wurtele, G.; Bartsch, H.; Owen, R.W. (2010): Evaluation of the polyphenol content and antioxidant properties of methanol extracts of the leaves, stem, and root barks of Moringaoleifera Lam. J. Med. Food, 13, 710-716.

Banchroft, J.D.; Stevens, A. and Turner, D.R. (1996): Theory and Practice of Histological Techniques. Fourth (ed). Churchil Livingstone, NewYork, London, San Francisco, Tokyo, $125 \mathrm{pp}$.

Bodakhe, S.H. and Ram, A. (2007): Hepatoprotective properties of Bauhinia variegata bark extract. YakugakuZasshi; 127: 1503-1507.

Brown, J. M.; Ball; J. G., Wright, M. S.; Meter, S. V. and Valentovic, M. A. (2012): Novel protective mechanisms for S-adenosyl-1-methionine against acetaminophen hepatotoxicity: Improvement of key antioxidant enzymatic function. Toxicology Letters, 212: 320-328.

Das, S. and Kanodia, L. (2012): Effect of ethanolic extract of leaves of MoringaoliferaLam. on acetic acid induced colitis in albino rats. Asian J Pharm Clin Res, 5 (3): 110 114.

Fahey, J.W. (2005). A review of the medical evidence for its nutritional, therapeutic and prophylactic properties. Trees life J., $1: 1-5$. 
Fakurazi, S.; Hairuszah, I. and Nanthini, U. (2008): Moringaoleifera Lam prevents acetaminophen induced liver injury through restoration of glutathione level. Food Chem. Toxic., 46: 2611-2615.

Gella, F. J., Olivella, T., Cruz Pastor, M., Arenas, J., Moreno,R., Durban, R. and Gomez, J.A. (1985): A simple procedure for routine determination of aspartate amino transferase and alanine amino transferase with pyridoxal phosphate. Clin. Chim. Acta., 153:241-247.

Goldberg, D.M. and Spooner, R.J (1983): In Methods of Enzymatic Analysis (Bergmeyen, H.V. Ed.) 3rd edn. vol 3, pp 258-265, VerlogChemie, Deerfield Beach,. Fl.

Hamza, A. A. (2010): Ameliorative effects of Moringaoleifera Lam seed extract on liver fibrosis in rats. Food Chem. Toxic., 48:345-355.

Jaeschke, H. andBajt, M.L. (2006): Intracellular signaling mechanisms of acetaminopheninduced liver cell death. Toxicol. Sci., 89 (1): 31-41.

Khalafalla, M.M.; Abdellatef, E.; Dafalla, H.M.; Nassrallah, A.A.; Aboul-Enein K.M.; Lightfoot, D.A.; El-Deeb, F.E.; El-Shemy, H.A. (2010): Active principle from Moringaoleifera Lam leaves effective against two leukemias and a hepatocarcinoma. Afr. J. Biotechnol., 9:8467-8471.

Larson, A.M. (2007): Acetaminophen hepatotoxicity. Clin. Liver Dis., 11 (3): 525-548.

Moyo, B.; Oyedemi,S.; Masika,P.J. and Muchenje, V. (2012): Polyphenolic content and antioxidant properties of Moringaoleiferaleaves extracts and enzymatic activity of liver from goats supplemented with Moringaoleifera leaves/sunflower seed cake. Meat Science, 91: 441-447.

Nadro, M.S., Arungbemi, R.M., Dahiru, D., (2005): Evaluation of Moringaoleifera leaf extract on alcohol-induced hepatotoxicity. Trop. J. Pharmaceut. Res., 5 (1): 539-544.

Nishikimi, M.;Rao, N.A. and Yagi, K. (1972): The occurrence of superoxide anion in the reaction of reduced phenazinemethosulfate and molecular oxygen. Biochem. Biophys. Res. Commun., 46: 849-854.

Oinam,N.;Urooj,A.;Phillips,P.P.andNiranjan, N. P. (2012): Effect of dietary lipids and drumstick leaves (Moringaoleifera) on lipid profile \& antioxidant parameters in rats. FoodNutr. Sci., 3:141-145.

Onkawa, H.; Ohishi, N.; Yagi, K. (1979): Assay for lipid peroxides in animal tissues by thiobarbituric acid reaction. Anal. Biochem., 95, 351-358.

Reeves, P.G.; Nielsen, F.H.; Fahey, G.C. Jr. (1993): AIN-93 purified diets for laboratory rodents: final report of the American Institute of Nutrition writing committee on the reformulation of the AIN -76A rodent diet. J. Nutr., 123, 1939-1951.

Rosalki, S.B.; Foo, A.Y. andBurlina, A. (1993): Multicenter evaluation of iso-ALP test kit for measurement of bone alkaline phosphatase activity in serum and plasma. Clin. Chim., 39:648-652.

Russmann, S.Gerd, A. andGrattagliano, I. (2009): Current concepts of mechanism in drug induced hepatotoxicity. Curr Med Chem, 16: 3041-3053.

Siddhuraju, P. and Becker, K. (2003): Antioxidant properties of various solvent extracts of total phenolic constituents from three different agro climatic origins of drumstick tree (Moringaoleifera Lam.). J. Agric Food Chem., 15: 2144-2155. 
Snedecor, G.W. and Cochran, W.G. (1980): Statistical methods. $7^{\text {th }}$ (ed). Iowa state University Press, Ames, Iowa, USA.

Sofidiya, M.O.;Odukoya,O.A.;Familoni, O.B. and Inya-Agha, S.I. (2006): Free radical scavenging activity of some Nigerian medicinal plant extracts. Pak. J. Biol. Sci., 9: 1438-1441.

Uma, N.; Fakurazi, S. and Hairuszah, I. (2010): Moringaoleifera enhances liver antioxidant status via elevation of antioxidant enzymes activity and counteracts paracetamol-induced hepatotoxicity. Mal. J. Nutr. 16 (2): 293- 307.

Verma, A. R.; Vijayakumar, M.; Mathela,C. S. and Rao, C. V. (2009): In vitro and in vivo antioxidant properties of different fractions of Moringaoleifera leaves. Food and Chemical Toxicology 47: 2196-2201.

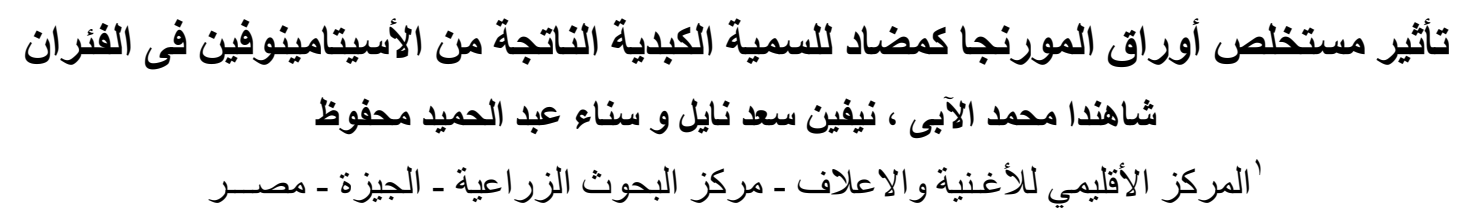

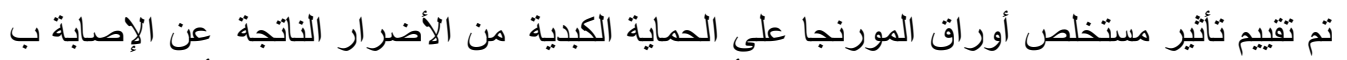

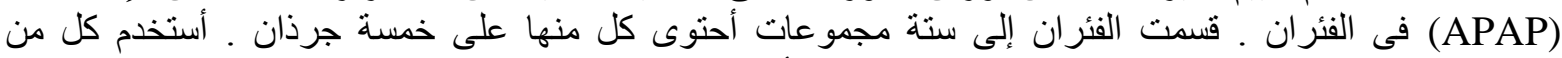

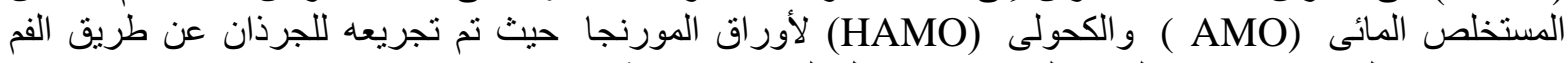

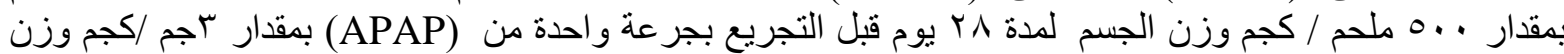

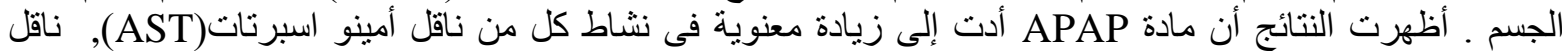

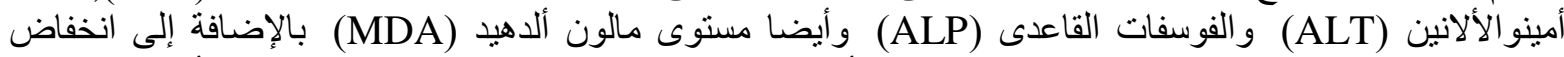

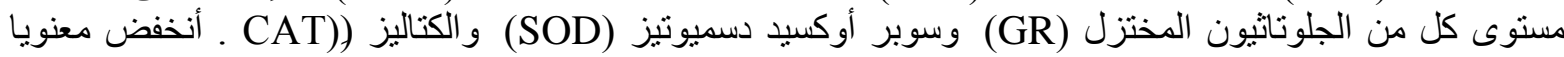

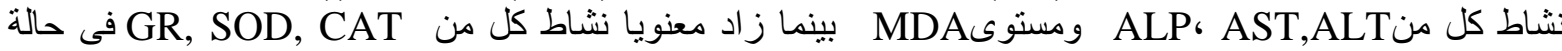

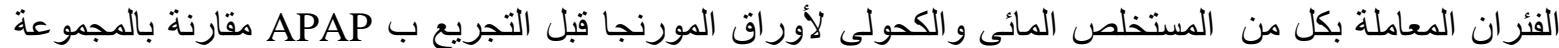

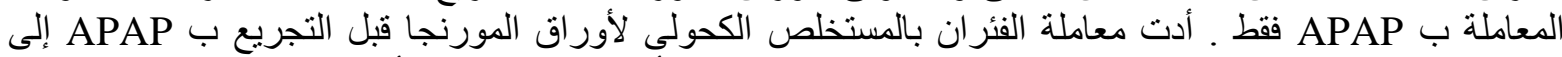

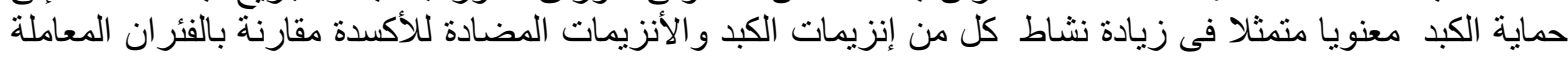

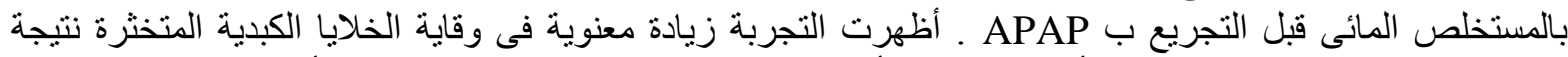

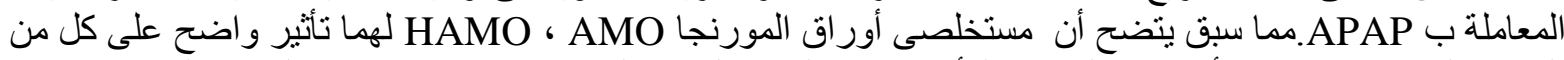
الحماية الكبدية و نشاط الأنزيمات المضادة للأكسدة ضد التسمم الكبدى الناتج عن (APAP) فى الفئران التجارب. 
